\title{
Bentham, Mill, Grote, and An Analysis of the Influence of Natural Religion on the Temporal Happiness of Mankind CATHERINE FULLER Bentham Project, University College London
}

This paper investigates the production of An Analysis of the influence of natural religion on the temporal happiness of mankind, first published in 1822 by George Grote, from Bentham's manuscripts on the utility of religion. The paper undertakes a preliminary comparison between the manuscripts and the book. The basis of this comparison also includes Grote's essay on Magic, the influence of James Mill, and Bentham's reaction to the book. It will be argued that Bentham and Grote had different agenda, and produced different texts, and that to regard Bentham as the author of $A n$ Analysis of the influence of natural religion is misleading. ${ }^{1}$

Denied the possibility of a university education by his father's insistence that he worked in the family bank, George Grote sought all possibilities of education and debate through friendship, and in 1819 met James Mill. ${ }^{2}$ Grote soon came under Mill's influence, and according to Harriet, Grote's wife, 'there was little difference in point of opinion between them'. 3

Grote's early essay on Magic, completed by Christmas $1820,{ }^{4}$ was a thinlydisguised attack on religion. Mill recommended Grote and the essay to the editor of the Encyclopaedia Britannica, and recommended Grote to Bentham as an editor of his writings on the utility of religion. ${ }^{5}$ After two meetings at dinner with Grote in August and November 1821, Bentham sent four parcels of manuscripts to Grote at his home above the family bank in Threadneedle Street. ${ }^{6}$ The last parcel was sent on 18

\footnotetext{
${ }^{1}$ A version of this paper was given at the ISUS Conference held in San Francisco in September 2008.

${ }^{2}$ George Grote (1794-1871) later became a member of the Utilitarian Society run by John Stuart Mill, and the Political Economy Club: he had joined the community which was to become the Philosophic Radicals.

${ }^{3}$ Mrs Grote, The Personal Life of George Grote, London, 1873, p. 22. For an example of the closeness of the thought of Mill and Grote in their private writings, see Postscript below.

${ }^{4}$ BL Add. MS 29,531, fos. 1-65, 67-88v, dated, by Harriet Grote, Christmas 1820.

${ }^{5}$ In January 1821.

${ }^{6}$ Colls Journal BL Add. MS 33,563, fos. 92-4. We can tell from the record kept by Colls, Bentham's amanuensis, how many and when the manuscripts were sent to Grote. The manuscripts now in the British Library are still bound in the same parcels, among which is Grote's plan, probably for second part of his work, written on the back of a cover sheet for a letter dated 3 December 1821; BLAdd. MS
} 
December 1821. Grote returned all the manuscripts to Bentham on 5 November 1822, and on the same day Richard Carlile the publisher sent Bentham a copy of the printed work, which it had taken Grote under a year to complete. ${ }^{7}$

\section{I}

What did Bentham send to Grote? Over 1,500 manuscripts. These represented all his work on the utility of religion-from the earliest paragraph, dated 10 July 1807, headed: 'Ch. 1. Utility of Religion a subject little as yet examined', 8 which was the introduction to a modest two-part work, to his most recent thoughts of November $1821^{9}$ for a much larger eight-part work. ${ }^{10}$ In these manuscripts Bentham addressed a mixture of current and traditional debates on religion. He used his own terms of reference and his own developing ideas, and he focussed on the irrelevance of religious belief, and the relevance of the principle of utility to human concerns. During the course of the work Bentham put forward a rationale for a secular state ${ }^{11}$ and a secular morality ${ }^{12}$ in accordance with his principle of utility. However, both the proposed title, 'The Usefulness of Religion to the present life examined', and the text itself stop short of an insistence on the replacement of religion with the principle of utility, and Bentham intended this to be so. His writings on religion reveal that he had a fear of prosecution, and of causing offence, for above all he wished to

\footnotetext{
29,807 , fo. 195 .

${ }^{7}$ Colls Journal BL Add. MS 33,563, fo.1 12.

${ }^{8}$ Bentham continued: 'While meditating on the subject of religion, and in particular on the influence which the notions presented by that term have or have been supposed to have on the welfare of mankind during the present life, it has frequently occurred to me, that after so much as has been said on both sides on the question respecting truth ... yet the question concerning their utility with reference to the present life, together with reference to a life to come, has never yet been placed in a full and satisfactory point of view'. see BL Add. MS 29,809, fo. 313, written at Barrow Hill House, Oxted, Surrey. While at Ford Abbey, Bentham did address the question of truth, see below.

${ }^{9}$ Bentham wrote on the utility of religion for the last time on 30 September 1830, UC cxxxviii. 162-5, 166.

${ }^{10}$ For a plan of the eight-part work, at BL Add. MS 29, 807, fos. 217-1 8, dated 8 January 1820, see Appendix at http://www.ucl.ac.uk/Bentham-Project/journal/cfapp.pdf. Other plans, in which there are slight variations in order and text, are at BL Add. MS 29,807, 173v, 8 January 1820, and BL Add. MS 29,807, fos. 157-8, 3 and 10 March 18211.

${ }^{11}$ Bentham wrote: 'Had the discourse of Jesus taken for its object the felicity of mankind during the present life, and in the pursuit of that object had his precepts been under the guidance of that degree of intelligence and wisdom of which human reason without any assistance from religion-without any assistance supernaturally given by and received from God-is susceptible, the following or thereabouts is the course he would have pursued'. He would have codified the different species of transgression under the title of crimes and misdemeanours. But, as far as Bentham was concerned, Jesus was neither a utilitarian nor a codifier of a penal code. BL Add. MS 29,807, fo. 58, 2 October 1811.

${ }^{12}$ See notes 48 and 49 below.
} 
preserve the integrity of his other works. ${ }^{13}$

The earliest drafts of 1810 on the utility of religion reveal Bentham's use of personal psychology - the general constitution of human nature-as the organizing factor, based on terms of reference and ideas outlined earlier in An Introduction to the Principles of Morals and Legislation. ${ }^{14}$ Within a year Bentham had abandoned the scheme, though not the substance, and reorganized his material around the concepts of Reason and Revelation, ${ }^{15}$ which finally, in 1819 , became Natural and Revealed Religion, categories commonly used by many other commentators at the time. ${ }^{16}$

By the end of 1811 Bentham envisaged a four-part work, and, in material eventually placed in Part I, 'On the Usefulness of Religion at large, verity apart', and Part II, 'On the Usefulness of Natural Religion, verity considered', ${ }^{17}$ Bentham continued to explore the uselessness and perniciousness of the religious sanction, and began to examine the attributes of God. Without Revelation, expectation of punishment or reward might be formed from our knowledge of the attributes of God such as Benevolence, Justice, Wisdom, etc. ${ }^{18}$ Bentham wrote: 'From our experience of the world, God is more malevolent than benevolent'. In fact 'if what is called God's justice does not bear benevolence in the same ratio as man's justice, tyranny is its proper name'. ${ }^{19}$ Disputes over the attributes of God had been commonplace in

\footnotetext{
${ }^{13}$ BL Add. MS 29,807, fos. 67-92, 31 August 1811; 29,806, fos. 305, 423, 28 September 1815; 29,809, fos. 352-3, 26 April 1819; 29,807, fo. 158, 12 March 1821.

${ }^{14}$ Principally the efficacy of human sanctions, the inefficacy of religious sanctions, and the principles of asceticism and antipathy. See Bentham, Introduction to the Principles of Morals and Legislation, ed. J. H. Burns and H. L. A. Hart, London, $1970(C W)$. The work was printed in 1780, and published in 1789. Hereafter IPML.

${ }^{15}$ See also BL Add. MS 29,809, fo. 357, 25 April 1815.

${ }^{16}$ BLAdd. MS 29,809, fo. 289, 16 February 1819; 29,809, fo. 374, 1 May 1819; 29,809, fo. 21, 21

March 1821.

Perhaps Bentham resisted the opposing categories of Natural and Revealed Religion, because the two were harder to keep distinct than reason and revelation. See BL Add. MS 29, 807, fo. 148, 14 October 1821: 'to extricate them from this entanglement, considerable care will be necessary'.

${ }^{17}$ See Appendix at http://www.ucl.ac.uk/Bentham-Project/journal/cfapp.pdf.

${ }^{18}$ At the end of his exploration of God's attributes Bentham resolved: 'not to wander long in the labyrinth of attributes', but he was unable to keep to his resolution, and in fact wandered in the labyrinth for years. See BL Add. MS 28,809, fos. 112-28, 268-76, 23 and 27 August 1811; BLAdd. MS 29, 809, fos. 280-5, 29 April 1819, 29,809, fos. 280-8, 29 April 1821, 29,809, fo. 330, 19 February 1821. And 'Here then we have a sample $\&$ a proof of this supposed compound of superhuman wisdom, put into action by superhuman benevolence. God makes men for the accomplishment of a certain purpose: when made it turns out that they are not fit for the purpose $\&$ that the purpose never is accomplished. Seeing this he falls into a passion, he punishes them for the disappointment produced by his not having been willing or not having been able - this all-powerful $\&$ all wise being to provide for the accomplishment of his own designs. Being angry he is thereby in a state of sufferance: he looks out for something to diminish this sufferance: $\&$ the only thing he can find capable of contributing to this effect is the prospect of the misery of these beings that accordingly he has made for the pleasure of seeing them miserable'. BL Add. MS 29,807, fo. 22, 5 September 1821.

${ }^{19}$ BL Add. MS 29,809, fo. 270, 28 August 1811.
} 
writings on religion for centuries, but Bentham provided the test of utility against which to judge God. God is not benevolent, but the principle of utility is, based on benevolence through justice.

For Bentham the influence of revealed religion was mischievous, and he began to list these mischiefs in Part V, 'On the Usefulness of Religion of Jesus, verity apart'. ${ }^{20}$ Some of the mischiefs Bentham found through the principle of asceticism which privileges pain over pleasure, and the principle of antipathy which encourages hatred of those who subscribe to different religious beliefs and practices-both first identified in IPML; other mischiefs were found in the traditions and customs of the church which had accrued through the centuries; and some in the Sermon on the Mount. In 1819, he reorganized the list into three categories: ${ }^{21}$ Mischiefs applying to man's feelings, for example, producing unassuageable terrors by threats of the torments of hell; To man's intellect, for example, acknowledging as true doctrines such as original sin for which God continually punishes mankind (Bentham wrote: original sin 'Original nonsense. Original disobedience to precepts never delivered'); and To man as a member of society, for example, encouraging disinterestedness and idleness: 'consider the lilies of the field, how they grow, they toil not' ${ }^{22}$

In 1811 two further parts were projected, though little worked upon in these manuscripts: 1 . on the influence of the established church, and 2. on how to reduce the influence of the Church to a minimum. Bentham wrote brief plans for measures on freedom of speech and worship. Freedom, of religious beliefs and personal tastes, is a thread which runs through Bentham's writings on religion.

The eight-part division of the text began to take shape while Bentham stayed at Ford Abbey in Dorset from 1814 to $1818 .{ }^{23}$ Putting utility to one side, he looked now at the truth of religion, under two headings of Verity Apart (presuming for the purpose of argument religion to be true), and Supposed Verity Considered (considering the truth

\footnotetext{
${ }^{20}$ See Appendix at http://www.ucl.ac.uk/Bentham-Project/journal/cfapp.pdf.

${ }^{21}$ BL Add. MS 29,806, fos. 519-20v, 18 April 1819. Bentham reworked and wrote new material on religion at this time. I think he may have planned to publish something in America, for on 29 November 1819 Aaron Burr wrote to Bentham: 'If you will send me your Work on Religion, I will publish it without delay and under any restrictions which you may impose'. See Letter 2577, The Correspondence of Jeremy Bentham, vol. ix, ed. S. Conway, Oxford, 1989 (CW), p. 370.

${ }^{22}$ The Church Fathers from Augustine onwards and philosophers had found the morality taught in the New Testament and the Sermon on the Mount in particular very demanding, (e.g. give away all possessions, and do no evil that good may come, termed by Bentham anarchical precepts), and had looked to Greek philosophy as a basis for moral thinking.

${ }^{23}$ At Ford Abbey he also worked on Church-of-Englandism and Not Paul, but Jesus.
} 
of religion), as two subsidiary principles around which to arrange his text. ${ }^{24}$ Bentham acknowledged transcendent truth neither in the matter of religion, nor in the matter of the idea of the sacred, since he acknowledged no transcendent truths whatever, and since the complex phenomena of the metaphysical aspects of religion simply did not interest him. He did not accept the possibility of any nuance of spiritual apprehension of divine truths beyond the experience of the senses. For Bentham there was no such thing as the verity of religion, only the persuasion of its verity, and the consequent expectations of supernatural punishments and rewards. For Bentham truth or verity was a matter of evidence: ${ }^{25}$ Natural Religion provided circumstantial evidence which was based on groundless suppositions or assumptions; and Revealed Religion provided direct evidence which on inspection turned out to be groundless and/or untrustworthy. ${ }^{26}$

In Part III, 'On the Usefulness of Revealed Religion at large, verity considered', ${ }^{27}$ to examine the supposed verity of religion, Bentham looked generally at the accounts of miracles and prophecies in the texts of revealed religions (Abrahamic religions) ${ }^{28}$ For the same Part he also redrafted sections from an essay on the current debate on miracles, credulity, and probability, ${ }^{29}$ initially proposed for his work on evidence. $^{30}$ The essay was begun in 1804 on Hume's Essay on Miracles, and included a critique of Price's theory of the probability of improbable things. ${ }^{31}$ For IV, 'On the

\footnotetext{
${ }^{24}$ Each manuscript carries some indication of the section into which it should be placed. Under the acerbic headings 'apparent verity considered', or 'supposed verity considered', Bentham examined Verity, often under the abbreviated general heading of Jug. True. He headed other manuscripts on Natural and Revealed Religion, Without Revelation and Under Revelation, often abbreviated to sine rev and sub rev. The general title of the whole work was abbreviated to Jug. Util. For the use and significance of Jug. see below.

${ }^{25}$ Bentham had stated this in the 1770 s. A Comment on the Commentaries and A Fragment on Government, ed. J. H. Burns and H. L. A. Hart, London, $1977(C W)$, p. 26: 'The question concerning the truth of the sacred history in general is a very complicated and difficult question of evidence ... '. ${ }^{26}$ See, for example, BL Add. MS 29,806, fo. 275, 25 January 1814; 29,806, fos. 365-9, 19 January 1815; 29,807, fo. 152, 2 March 1821. The majority of the manuscripts at BL Add. MS 29,806 are on the topic of the truth of religion, headed Jug True.

${ }^{27}$ See Appendix at http://www.ucl.ac.uk/Bentham-Project/journal/cfapp.pdf. See BL Add. MS 29,806, fos. 23-5, 242-9, 365-72, 427-8, 474-89, 261-75, all written in January 1814. BL Add. MS 29,809, fos. 357-61, 25 April 1815.

${ }^{28}$ For the Abrahamic religions see, for example, BL Add. MS 29,806, fo. 395, July 1815; BL Add. MS 29,806, fo. 247,27 March 1814; BLAdd. MS 29,809, fo. 15, 12 March 1821.

${ }^{29}$ See D. Wootton, 'Hume's “Of Miracles": Probability and irreligion', Studies in the Philosophy of the Scottish Enlightenment, 1990.

${ }^{30}$ But in 1811 he wrote 'Omitt out of evidence, this being polemical, and anti-juggernaut post off to the anomyn work', i.e. anomyn: disregard of law, disregard of divine law. BL Add. MS 29,806, fo. 174.

${ }^{31}$ The work was entitled Antimir: i.e. against wonder-works. See BL Add. MS. 29,806, fos. 142-9, November 1806; 174-7, December 1808; 70-1, January 1809; 66-9, 172, 158-63, November 1811; 1513, November 1812; 119-40, November 1813; and specifically intended for religious writings 29,807, fos. 120-5, March 1819.
} 
Usefulness of the Religion of Jesus, verity considered in the general point of view', ${ }^{32}$ Bentham then exposed the supposed verity of the Religion of Jesus, through the discordancy, and therefore lack of truth, in the received accounts of the miracles of Jesus in the New Testament, and the 'disfulfillment' of his predictions. ${ }^{33}$

Within a large wrapper containing 392 manuscripts ${ }^{34}$ is work for Part VI, 'Jesus Displayed: or the History of Jesus as deduced from a critical examination of the documents'. Here Bentham examined a subject explored by German Enlightenment thinkers ${ }^{35}$-Jesus' own temporal ambition. ${ }^{36}$ '[Jesus'] sole purpose' Bentham wrote, 'was to raise up a temporal sovereignty for himself in that country at that time; and to this end every discourse as well as every act will, upon examination ... be... found to be directed'. ${ }^{37}$ But as hope of success faded, a spiritual rather than a temporal kingdom was invented. For Bentham, the precepts in the Sermon on the Mount, from which he had earlier identified many Mischiefs, now became evidence of this mission. ${ }^{38}$ Bentham held that for the individual and the purpose of the moment all these precepts were perfectly well adapted, but for 'the universally and perpetually necessary purposes of human society, these precepts were destructive' ${ }^{39}$

From time to time Bentham added to these manuscripts ideas he had developed

\footnotetext{
${ }^{32}$ See Appendix at http://www.ucl.ac.uk/Bentham-Project/journal/cfapp.pdf.

${ }^{33}$ See UC cxxxviii. 1-139, dated March to September 1815. Most of the work Bentham completed on this topic, entitled 'Comparative Study of Accounts of the Life of Jesus in the gospels', is stored at UCL and so may not have been sent to Grote. Bentham composed tabulations of Jesus' prophecies and miracles, categorized into type: cures, dispossessions, sea miracles, vegetation destroyed, and cures divided again into blindness, leprosy, palsy, fever, bedriddenness etc.

${ }^{34}$ BL Add. MS 29,806, fo. 8, n.d. BL Add. MS 29,806, fos. 008-118, 301-495.

${ }^{35}$ The German deist, Herman Samuel Reimarus (1694-1 768), is generally regarded as having first proposed these ideas, which remained as notes only until his work was published posthumously and anonymously by one of his followers, Gotthold Ephraim Lessing, in 1774 and 1777. The ideas certainly had currency among scholars in Germany and in England when Bentham was writing. For example: Herbert Marsh (1757-1 839), biblical scholar, Bishop of Llandaff 1816-19, Bishop of Peterborough from 1819; Thomas Beddoes (1760- 1808), chemist and physician; and the Romantic poet Samuel Taylor Coleridge (1 772-1834), see E.S. Shaffer, “ "Kubla Khan” and The Fall of Jerusalem', The Mythological School in Biblical Criticism and Secular Literature 1770-1880, Cambridge, 1975. Goethe left among his unpublished notes the statement: 'The Christian religion was an intended political revolution, which, after failing, subsequently became an ethical one'. All three, Bentham, Reimarus, and Goethe, left their thoughts in unpublished manuscripts, and the subject was not really tackled openly until the late nineteenth and early twentieth century.

${ }^{36}$ BL Add. MS 29,806, fo. 332, 8 August 1815. See also within Bentham's critique of the Lord's Prayer-'Thy Kingdom Come: The Kingdom described by all prophets as temporal was found to be spiritual', BL Add. MS 29,808 fo. 153, 19 September 1811.

${ }^{37}$ BL Add. MS 29,806, fo. 302, March 1815. Bentham surmised that the plan originated with Zachariah, father of John the Baptist. As a priest, Zachariah, who was privy to the secrets of government, probably intended his own son to lead the Jews, not John's cousin Jesus, the son of a carpenter, but Jesus' eloquence and charisma made him a better candidate for the task.

38 'These precepts ... what had they for their object? The accomplishment of his own project of temporal ambition — that and nothing else'. BL Add. MS 29,807, fo. 44, 17 July 1815.

${ }^{39}$ BL Add. MS 29,807, fo. 45, 17 July 1815.
} 
first elsewhere. In July 1815, Bentham examined aspects of religion using his theory of fictitious entities, developed in his work on language and logic undertaken ten months earlier. ${ }^{40} \mathrm{He}$ had identified fictitious entities as things that were spoken of as if real but were not, and developed interpretative processes (phraseoplerosis and paraphrasis), used notably with the terms such as duty and rights, to give such words 'a determinate meaning fit for discourse'. Using his theory of fictitious entities Bentham found, for example, that words such as God and soul could be identified as inferential real entities, or if that failed to persuade, non-entities. ${ }^{41}$ Bentham now revised a chapter on 'Life after death—its natural improbability', and asked a series of questions designed to embarrass the proponents of resurrection: After death, what happens to the mind or soul, ${ }^{42}$ in what state will the mind be preserved? as it was in old age at the point of death, or in youth ${ }^{43}$ Bentham had already decided on the only sensible answer: the mind or soul is a cluster of fictitious entities-mental faculties such as perception, memory, judgment, etc. ${ }^{44}$ — existing only through the medium of a living body. After death we, and our soul, cease to be. This discussion became part of Part II, 'On the Usefulness of Natural Religion, verity considered' ${ }^{45}$

In 1819 Bentham redrafted and refined his writings of 1811 on the efficiency of human sanctions incorporating ideas from his work on sanctions dating from 1814 on Logic and later on Deontology. He extended the number of sanctions to seven. ${ }^{46} \mathrm{He}$

\footnotetext{
${ }^{40}$ UCL cii. 9, 11, 15, 25-27 September 1814.

${ }^{41}$ UCL cii. 11,26-7 September 1814.

${ }^{42}$ Bentham uses the word soul to mean qualities of the mind, rather than the immortal spirit of man, in line with contemporary usage. (See, for example, Samuel Johnson, Dictionary of the English Language, first published 1755).

${ }^{43}$ And if a degree of intelligence is the criterion for resurrection, then should some animals be resurrected? BLAdd. MS 29,809, fos. 154-62, 15 July 1815, ibid., 29,809, fos. 384-91,24 February 1819.

${ }^{44}$ BL Add. MS 29,809, fo. 162, 21 July 1815.

${ }^{45}$ In a draft introduction, Bentham ended with the hope that eventually substances such as soul and God might, like heat and light, be considered as no more than an affection of the world (i.e. a property, quality, or attribute, and therefore a fictitious entity), not objects of prosecution, or affected or real hatred, but considered with mutual forbearance and good humour. BL Add. MS 29,809, fo. 376, 15 July 1815. In August 1816 he added a note on the term spirituality, which he identified as a fictitious entity but used neither forbearance nor good humour when doing so: he wrote 'spirituality-the idea was an engine in the hands of impostors for dragging in dupes'. BL Add. MS 29,806, fo. 333, 6 August 1815. Later he identified religion as a fictitious entity: see BL Add. MS 29,809, fos. 9-12, 7 March 1819.

${ }^{46}$ Six sanctions: BL Add. MS 29,809, fos. 64-7, 17 February 1819. Seven sanctions: BL Add. MS 29,809, fo. 58, 24 February 1821, and ibid., fos. 25-30, March 1821. The extension of sanctions from four to seven was a topic of correspondence from October 1821-November 1822 with Dumont, who was keen to have details of the expanded list, and whether he should include the new list in the third edition of Traités de législation, though no expanded list appeared in the third edition of 1830. See Letters 2794, 2815, 2820, 2824, The Correspondence of Jeremy Bentham, vol. x, ed. S. Conway, Oxford, 1994 ( CW), and Letters 2821, 2913, 2918, 2936, The Correspondence of Jeremy Bentham, vol. xi, ed. C. Fuller, Oxford, $2000(C W)$. In exasperation Bentham wrote to him in May
} 
examined the sympathetic sanction, that is action undertaken in sympathy for others, ${ }^{47}$ of which he had written: 'were it not for the operation of [the sympathetic] sanction, no small portion of the good ... which has place in human affairs, would be an effect without a cause' ${ }^{48}$ This material helped Bentham combat the argument of those who did not believe in religion, but believed that without religion morality and human society would end. ${ }^{49}$ Not so, said Bentham. This point also perhaps prompted a moral dimension to the mischiefs in a fourth category of mischiefs that apply to the moral part of man's frame. ${ }^{50}$

In March 1821, clarifying the purpose of the work, Bentham revealed his political agenda. He identified two motives: to free men from terrors and useless privations of which religion is the source, and to destroy the powers of government that employ these forces for the oppression of the subject many. ${ }^{51}$ In October he added further clarification: 'direct object: maximize converts, collateral object: avoid sufferance at the hands of the political and popular or moral sanction, and suppression of this work. How? minimize irritation, attack natural religion first, giving your enemy as long as you can a loop-hole to creep out at'. And Grote took this advice. $^{52}$

The plan in the Appendix does not reflect the organization of the manuscripts Bentham sent. What Grote received were drafts and redrafts, notes and summaries, tied up in parcels of manuscripts vaguely arranged on utility, truth,

1822, ibid., 86: 'A sheet, to which this exemplification [of drunkenness in the seven sanctions] had been consigned, has found its way - to the moon, I imagine, for upon earth I can not find it'. In fact, the paper in question was among Bentham's religious writings which were with George Grote at this time.

${ }^{47}$ BL Add. MS 29,809, fos. 228-9, 18 February 1819.

${ }^{48}$ See BL Add. MS 33,550, fo. 31, 11 November 1814, also Bowring, iii. 292 'Logical arrangements, or Instruments of invention and discovery'. In the religious writings Bentham wrote at BL Add. MS 29,809, fo. 94, 18 February 1819: 'by the sympathetic sanction is left, in the instance of each individual, the care of the happiness of all other individuals, in so far as their happiness is at stake upon his conduct'. And at BL Add. MS 29,809, fo. 26, 11 March 1821: 'If of any one of the human sanctions the tendency were purely good it would be the sympathetic sanction. If of any one of the human sanctions the tendency were purely evil, it would be the antipathetic sanction. But in the case of the sympathetic spring the goodness of its effect and tendency depends altogether upon, and is measured by, the extent of the good to the production of which it tends'.

${ }^{49}$ BL Add MS 29,809, fo. 98, 29 April 1819: 'It is an opinion commonly professed-and it is believed not uncommonly entertained-that religious belief is the only support which morality, which good moral conduct has, that if religious belief were at an end, morality would be at an end, and that with it human society would be at an end. ... How far this opinion is conformable to truth, will it is believed be seen as we advance'. As early as c. 1776 Bentham had accused religionists of having an interest in the depression of moral science: see UC 1xix. 166.

${ }^{50}$ See Appendix at http://www.ucl.ac.uk/Bentham-Project/journal/cfapp.pdf. Part V, Section IVwas added on 21 April 1819.

${ }^{51}$ BLAdd. MS 29,807, fos. 157-162 at 157, 10 March 1821.

${ }^{52}$ BL Add. MS 29,807, fo. 147, 14 October 1821. 
mischiefs, and marginal summaries. It would be the work of many months if not years to determine a text from this plan.

\section{II}

In some ways a comparison between Bentham's manuscripts and Grote's text is imprudent. Contextually the first is written by an old man with a lifetime's dedication to the principle of utility, a body of work and a reputation throughout large parts of the French- and English-speaking world to defend, and a desire for reform; the second by a young man, rebelling against a home, as Grote wrote, overclouded with the 'deepest night of ignorance', ${ }^{53}$ just setting out in the world with nothing to lose, but a circle of young philosophic radicals to impress. Textually a comprehensive comparison of two such disparate texts presents a task fraught with many difficulties, for example of method, scale, and purpose - the task may even be impossible. Within the limits of this short paper I shall therefore attempt only a few initial comments.

Our knowledge of what Bentham thought of Grote's work comes from a letter Bentham sent to Jean Baptiste Say in August 1823. ${ }^{54}$ Bentham denied having met Grote, and disowned the work. His criticisms were second-hand, for he had not read the text. He confessed that Mill had warned him that Grote had 'a mode of writing of his own', which he would not change.

He was told that Grote had used uncommon words in preference to common ones (strange criticism coming from Bentham). Had Bentham read the work he might have quarrelled with Grote's use of the term extra-experimental belief. Grote had used the word experimental meaning relating to experience in his essay on magic, but the word was rarely used by Bentham in this way in these manuscripts. The term extra-experimental belief, which has since been attributed to Bentham, was never used by him. For Bentham the more pointed 'supposition' served his purpose well. Grote used the phrase in the enumeration of mischiefs to man's intellect: for example, inculcating an extra-experimental belief in God's creation of the world—knowledge of which cannot be found from observation and experience. ${ }^{55}$

\footnotetext{
${ }^{53}$ Specifically, the domination of his father and the harsh and ascetic form of religious belief of his mother: Grote to his sister in law, UCL MS ADD. 266/A2.12, 25 February 1823.

${ }^{54}$ Bentham to Jean Baptiste Say, Letter 2988, 4 August 1823, Correspondence $(C W)$, xi. 273-7. Why was Bentham so dismissive of the work, or rather, why did he defend his own work on religion to Say, whom Bentham knew was not a believer, and who had suggested Bentham's work Not Paul but Jesus, should be entitled Not Paul nor Jesus?

${ }^{55}$ Another use of a word which might have caused Bentham anxiety was the word Inducement.
} 
Bentham was also told Grote had included an attack on the Lord's prayer 'a sort of proceeding which, from first to last', Bentham added without a hint of irony, 'I had most religiously abstained from'. In fact Grote mentioned the Lord's Prayer only in passing within a sentence, ${ }^{56}$ but Bentham had included such an attack under the heading mischiefs to man's intellect ${ }^{57}$ in eight of the manuscripts he sent to Grote, and James Mill's Commonplace Book contains a copy of Bentham's marginal summary sheet for the manuscripts. For Bentham, each clause of the Lord's Prayer was found to be flawed, for example, the idea of forgiveness and atonement for sins-'Atonement i.e. abolition of penal retribution'. 58

Grote enlarged on Bentham's point that God's attributes cannot be equated with those of a benevolent human being, but with those of an earthly tyrant, a point which Grote had made in his essay on Magic. ${ }^{59}$ But Grote justified his claim on linguistic grounds: the use of praise and blame (God blames man indiscriminately, man praises God unreservedly).

Bentham's writing style, essentially of the eighteenth century, and often criticized as prolix, tiresome, and sometimes obscure, was not replicated by Grote. Neither was Bentham's use of small dialogues, which were often inserted as marginal summaries relating to texts of some complexity. The dialogue, a favoured tool of prose writers in the eighteenth century, provided a good way of making a point persuasively, mainly of course by asking the right questions and giving the answer most suited to your purpose. ${ }^{60}$ These dialogues however did not suit Grote's more modern style or purpose, and were omitted.

A fair summation of Grote's work as a whole is that it echoes Bentham's text and summaries, but it is rewritten to accommodate Grote's own thoughts, and in his own style. There are few direct and some indirect quotations from Bentham's

Grote used the material on sanctions, but frequently called them inducements, especially in chapter headings. Quite why is not clear. Perhaps he felt the word had connotations of punishment which inducement did not, although Bentham clearly stated that 'Inducements to take the right path were called Sanctions, whereas Inducements to take the wrong path were called temptations': see BL Add. MS 29,807 , fo. 27,18 November 1821 . Perhaps the word sanctions referred too specifically to IPML, and therefore Bentham. At one point in the first edition, and in all subsequent printed editions, the word appears mistakenly as Superhuman Enjoyments! See Analysis, p. 54.

${ }^{56}$ Grote, Analysis, p. 108.

${ }^{57}$ BL Add. MS 29,807, fos. 208-9, 3 October 1811 (marginal summaries), ibid., 29,808, fos. 152-9, 18 September 1811 (text).

${ }^{58}$ BLAdd. MS 29,808, fo. 121, October 1813.

${ }^{59}$ BL Add. MS 29,531, fos. 26-28.

${ }^{60}$ In these dialogues Caelestis[Heavenly spokesperson] argues with Mandamus[Earthly spokesperson], BL Add. MS 29,809, fos. 472-3, 19 May 1813; Heterodox argues with Orthodox, 29,806, fos. 441-2, 25 December 1814; and Ascetius[Ascetic] with Liberius[Liberal], 29,809, fo. 485, 22 May 1812. 
manuscripts, ${ }^{61}$ as well as from Grote's own essay on Magic. ${ }^{62}$ Had he read Grote's work, Bentham would have seen that the text contained only a small section of his own, as he advised, on Natural Religion: the first part examining the absence of directive rule to be found in Natural Religion, and therefore the efficiency of human sanctions, and the inefficiency of the superhuman sanction to the happiness of mankind; and for the second part Grote cherry-picked the polemical section on mischiefs from Part V, 'On the Usefulness of the Religion of Jesus, verity apart', and realigned the mischiefs within Natural Religion organized in two categories: to man himself, and to mankind in general.

Grote shared Bentham's fear of prosecution for publishing this work, and used a pseudonym. But this is not to say that Grote was not convinced by the work he produced. Grote wrote to his sister-in-law in February 1823: "when once you have thoroughly satisfied yourself that an action is sanctioned or commanded by the principle of utility. [You will see that T] his is the only rule which can possibly be delivered \& whoever lives without this, must really live without any rule at all' ${ }^{63}$ His sister-in-law's path to non-belief had begun with conversations with Grote on the principle of utility, and reading an essay by Mill on sentimental prejudice. ${ }^{64}$

\section{III}

We have noted above James Mill's influence on Grote and it seems entirely plausible that Mill was involved in discussions with Grote about his work on Bentham's manuscripts. We know also that Mill saw a copy of Grote's manuscript before publication, as John Stuart Mill made a summary of it. ${ }^{65}$ At the same time, I think we should not overlook Mill's contribution to Bentham's work. ${ }^{66}$ There is ample evidence that Mill was involved in Bentham's religious writings. ${ }^{67}$ In Mill's Commonplace Book

\footnotetext{
${ }^{61}$ See, for example, Grote, Analysis, pp. 1-3 + BL Add. MS 29, 807, fos. 18, 127; Grote, Analysis, pp. 48-9+ BL Add. MS 29,809, fos. 229-30; and Grote, Analysis, p. 97-8 + BL Add MS. 29,809, fo 152, 5 March 1821.

${ }^{62}$ For example, on tyrannical behaviour at 'Magic', BL Add. MS 29,531, fos. 26-8, and Grote Analysis, pp. 17-26. On Father Malebranche at 'Magic' BL Add. MS 29,531, fo. 26, and Analysis, p. 17. On miraculous events at 'Magic' BL Add. MS 29,531, fos. 55-6, and Analysis p. 103.

${ }^{63}$ UCL MS ADD. 266/A 12, 25 February 1823.

${ }^{64}$ UCL MS ADD. 226/A2.16, 28 January 1824.

${ }^{65}$ Autobiography and Literary Essays, ed. J. Robson and J. Stillinger, Toronto, 1965, (Collected Works of John Stuart Mill), i. 72-3, and Common Place Book of James Mill, London Library, ii. 73-5, 77-8.

${ }^{66}$ Bain, Mill's biographer, states that Mill worked with Bentham on his Chrestomathic plans, the Introduction to Rationale of Judicial Evidence, and Elements in the Art of Packing: A. Bain, James Mill, London, 1882, pp. 98-101.

${ }^{67}$ Mill's experience as a Minister of the Church of Scotland surely contributed to Bentham's knowledge of
} 
there are quotations from the Morning Chronicle and William Paley, which are used in Church-of-En glandism. Did Mill suggest these to Bentham, or did he copy them from Bentham? We cannot know. In Mill's Commonplace Book there are copies/summaries/versions of Bentham's earliest plans of 1811, some notes dating from Bentham's work in 1815, and manuscripts by Bentham on Church reform. ${ }^{68}$ The connection is an intimate one.

As well as the textual evidence, there is also the fact that Mill had been with Bentham from the early days of his writings on religion. Mill stayed with Bentham in September 1811 at Barrow Hill when Bentham first began to write extensively on the utility of religion, and at Ford Abbey while Bentham wrote a substantial amount of work on religion. ${ }^{69}$ Despite their relationship of master and disciple it seems impossible that they did not influence each other on the subject.

An article by Mill, published a year before his death, and three years after Bentham's death, in the London Review of 1835 entitled 'The Church, and Its Reform', ${ }^{70}$ contains evidence of Bentham's influence on topics such as the inefficacy of prayer, and the follies associated with belief in posthumous punishment. Mill refers flatteringly to Bentham's arguments in Church-of-Englandism, at one point commending a passage for instruction and amusement! But we can also see Mill's own agenda, for example, to reform the clergy through superintendence and inspection, and the clergy in turn to teach their parishioners at parochial assemblies. ${ }^{71}$ In this article Mill's aim appears to be to despiritualize the Church, to make it an instrument of 'much good', but not to make it redundant. He even jarringly at one point in the article refers to Jesus as 'Our Saviour', words a far cry from Grote's and Bentham's unemotive term for another member of the godhead: Invisible Being, Invisible Dispenser, Invisible Creator, Omnipotent Being.

\footnotetext{
the workings of that church.

${ }^{68}$ See, for example, London Library, James Mill Commonplace Book, vol. iv, fo. 80v + BL Add. MS 29,809, fo. 306 and 29,808, fos. 221, 192, 165-79; Mill Commonplace Book, vol. iv, fo, $81+$ BL Add. MS 29,807, fo. 276.

${ }^{69}$ We know that at Ford Abbey, Bentham and Mill worked in the same room all day, and discussed their work each evening during a walk around the grounds: Letter 2283, 19 July 1814, The Correspondence of Jeremy Bentham, vol. viii, ed. S. Conway, Oxford, 1988 (CW), viii. 404, and Francis to Elizabeth Place, 4 August 1817, Place Papers, BLAdd. MS 35,143, fo. 282.

${ }^{70}$ London Review (July 1835) i. 257-95.

${ }^{71}$ i.e. to teach art and science, and elements of politics and jurisprudence.
} 


\section{IV}

What can we say about these three men? Textually we can analyse and annotate their works to find direct quotations, common ground, and divergences. It is harder to extricate the intellectual and emotional ties in the master/pupil relationships. According to Harriet Grote, Bentham destroyed Mill's belief, Mill destroyed Grote's, and she was fairly argued out of the religion after her marriage. ${ }^{72}$ And they probably all influenced John Stuart Mill. ${ }^{73}$

The three men used the word Jug to refer to religion. Jug was an abbreviation of Juggernaut or Jagannath, an earthly incarnation of the Indian deity Krishna, an image of whom was dragged through the streets of Puri, in Orrisa, annually on a cart under whose wheels, it was believed, devotees threw themselves and were killed. This word conveyed precisely what they all considered to be the pernicious influence of religion. Jug also gave them a code word they could use, when talking of religion. ${ }^{74}$

The fact that none of them publicly asserted their unbelief, merely reflects the times in which they lived. Was atheism just an intellectual exercise for Mill and Grote, a subject for speculation? I think neither Mill nor Grote sought to convert the population of England into non-believers, but they were keen, as Bentham was, to point out the flaws in the systems of beliefs and practices inculcated by the church, and by this means suggest a rationale for unbelief. When Mill wrote the words Our Saviour was he looking more sympathetically at religion as he neared death? When Grote republished, again pseudonymously, An Analysis of Natural Religion in 1865, six years before his own death, did he do so to protect his reputation after death?

Both James Mill and Grote received Christian burials (Grote in Westminster Abbey). Only Bentham pursued his principles beyond, or rather outside the grave, and from his Auto- Icon demands still that we consider the utility of religion in the present life.

\footnotetext{
${ }^{72}$ The Amberley Papers, ed. B. \& P. Russell, 2 vols., London, 1937, i. 421: 'Mrs G. told us that James Mill's faith was destroyed when he came to London \& knew Bentham-\& that James Mill destroyed Mr. Grote's faith after he was grown up \& that he suffered much in giving up the old beliefs \& so did she after she was married; she says she was fairly argued out of it all'.

73 'It would have been totally inconsistent with my father's ideas of duty, to allow me to imbibe notions contrary to his convictions and feelings respecting religion ... I am thus one of the very few examples, in this country, of one who has, not thrown off religious belief, but never had it. I grew up in a negative state with relation to it'. See John Stuart Mill, Autobiography and Literary Essays, (Collected Works of John Stuart Mill), i. 44-5.

${ }^{74}$ See, for example, letters from Grote dated 28 January 1824 and 20 December 1826 at UCL MS ADD. 226/A2.16, and A2.20.
} 


\section{POSTSCRIPT}

In 1854 the word juggernaut, used by Bentham, Grote, and Mill forty years earlier as an apt synonym for religion, is recorded in the Oxford English Dictionary as being used for the first time in this figurative sense as an institution, practice, or notion to which persons blindly devote themselves, or are ruthlessly sacrificed.

In 1859 Darwin published The Origin of the Species.

In 1865 the clergy were required to affirm only a general assent to the 39 articles, the subscription to which, as a young graduate in 1763, had reverberated ominously throughout Bentham's life

In 1865 J.S. Mill published An Examination of Sir William Hamilton's Philosophy, which contained the passage: 'I will call no being good, who is not what I mean when I apply that epithet to my fellow-creatures; and if such a being will sentence me to hell for not so calling him, to hell I will go' ${ }^{75}$ J.S. Mill's published declaration echoes sentiments expressed only in the private writings of his father and Grote forty years before. ${ }^{76}$ Mill: 'The first article of any religion is the belief of an allperfect God. To that I stick. Whatever I cannot reconcile with that I reject. And so rejecting, I am freed to make sad havoc among what has been taught for religion in all ages \& countries, \& among all sects'; and Grote: 'I always reason upon the supposition of God being benevolent-for either he is benevolent or else there is no God-to me at least, in as much as I cannot know him or his character'.

In 1869 Thomas Huxley, Darwin's bulldog and a friend of the Grotes, coined the word agnostic, which may have suited Bentham well, to describe someone who thought God 'unknown and unknowable'.

In 1873 both John Stuart Mill's posthumous Autobiography and Alexander Bain's The Minor Works of George Grote, revealed Grote and Bentham as responsible for Analysis of the Influence of Natural Religion, which prompted two new editions of the work in 1875, at London and at Paris, acknowledging their authorship of the work for the first time.

\footnotetext{
${ }^{75}$ J. S.Mill, An Examination of Sir William Hamilton's Philosophy, London, 1865, p. 103.

${ }^{76}$ At London Library, J. S. Mill Commonplace Book, vol. iv, fo. 81 v, and UCL MS ADD. 266/A2.3, 1 June 1822.
} 


\section{(c) (1) $(9)$ \\ BY NC ND}

This work is licensed under the Creative Commons Attribution-NonCommercial-NoDerivs 2.0 UK: England \& Wales License. Under the terms of this licence, you are allowed to copy and distribute this work, but must give the original author credit. You not use this work for commercial purposes, nor alter or transform this work, without prior permission from the author. To view a full copy of this licence, visit: http://creativecommons.org/licenses/by-ncnd/2.0/uk/ or send a letter to Creative Commons, 444 Castro Street, Suite 900, Mountain View. 